\title{
Evaluation of Appropriate Identification of Deforestation Agents and Drivers for Designing REDD+ Readiness Activities through an Examination of the Area around Gunung Palung National Park, Indonesia
}

\author{
Toshihide Yoshikura1, Masahiro Amano1, Haruko Chikaraishi², Bambang Supriyanto3, \\ Dadang Wardhana ${ }^{3}$ \\ ${ }^{1}$ Faculty of Human Sciences, Waseda University, Tokorozawa, Japan \\ ${ }^{2}$ Mitsubishi UFJ Research and Consulting, Tokyo, Japan \\ ${ }^{3}$ Ministry of Environment and Forestry, Jakarta, Indonesia \\ Email: to.yoshikura@fuji.waseda.jp
}

Received 30 January 2016; accepted 12 April 2016; published 15 April 2016

Copyright (C) 2016 by authors and Scientific Research Publishing Inc.

This work is licensed under the Creative Commons Attribution International License (CC BY). http://creativecommons.org/licenses/by/4.0/

\section{(c) (i) Open Access}

\begin{abstract}
For effective REDD+ implementation with multiple readiness activities, agents and drivers of deforestation and forest degradation needs to be identified appropriately. This study examined how such identification can be utilized for instituting REDD+ activities design. We examined this question by using satellite imagery analysis and socioeconomic surveying around Gunung Palung National Park in Indonesia. After recognizing the deforestation rate in the area, the characteristics of agents and drivers of deforestation were explored by using statistical analysis. Several canonical discriminant analyses revealed that the agents and drivers could be classified effectively by using socioeconomic type rather than ethnic groups or geographical location. A principal component analysis and the associated scatter diagrams showed that various agents and drivers exist in a given area within the study region. Finally, these efforts led to the suggestion of options for REDD+ readiness activities based on the diverse features and underlying causes.
\end{abstract}

\section{Keywords}

REDD Plus, Gunung Palung National Park, Deforestation Driver, Readiness Activities, Socioeconomic Survey 


\section{Introduction}

Discussion about the Reducing Emissions from Deforestation and Forest Degradation plus additional measures (REDD+) scheme and modality has continued under the United Nations Framework Convention on Climate Change Conference (UNFCCC) since COP11, Montreal, in 2005. In decision 1/CP16 of the UNFCCC in Cancun, Mexico, in 2010, activities for developing technical capacities and institutional arrangements to be implemented in phases beginning with strategy development and demonstration activities with capacity building toward achieving results-based actions were encouraged (UNFCCC, 2010). Various preparatory actions and pilot activities in developing countries are on-going as REDD+ readiness actions in the phased approach for achieving policy and measures to create an enabling environment for REDD+ (Angelsen et al., 2009; Streck et al., 2009; Minang et al., 2014). In the Paris Agreement adopted in COP 21, the importance of reducing emissions from deforestation and forest degradation with sustainable forest management was emphasized (UNFCCC, 2015), and in the Intended Nationally Determined Contributions (INDCs) proposed by member countries of the UNFCCC, more than half of the countries made commitments in the forest sector including REDD+ (Petersen \& Varela, 2015).

In REDD+ implementation, actions to reduce drivers of deforestation and forest degradation through appropriate recognition of the drivers unique to each country's national circumstances will be essential, as affirmed in Decision 17/CP 19 of the UNFCCC in Warsaw (UNFCCC, 2013). Correct identification of agents and drivers of deforestation and forest degradation also will be essential for establishing appropriate targets and actions to achieve REDD+ (Kissinger et al., 2012; Minang et al., 2014). To identify specific key agents and drivers, the Verified Carbon Standard (VCS), one of the standards for carbon-related verification, methodology suggests combining several types of surveys and analyses (Shoch et al., 2011). Drivers of deforestation and forest degradation by unplanned activities can be divided into proximate drivers, such as logging and farm expansion, and underlying causes, which are interactions among various complex influences and agents (VCS, 2012). Then, omitting consideration of the underlying causes and focusing only on proximate drivers could minimize the impacts of measures for addressing those drivers (Angelsen \& Kaimowitz, 1999; Geist \& Lambin, 2001; Buys, 2007; Salvini et al., 2014). To explore measures for drivers as well as underlying causes, it will be important to appropriately understand specific local characteristics by integrating several methods, including socioeconomic surveys (Minang \& Noordwijk, 2013; Pasgaard, 2013; Epule et al., 2014). Based on this information and understanding, multiple readiness activities with appropriate target scales or levels can be programmed for effective REDD+ implementation (Angelsen et al., 2009; Akiefnawati et al., 2010; Caplow et al., 2011; Agung et al., 2014; Sunderlin et al., 2014).

Indonesia has ideal relevance for REDD+ efforts because of its eighth-largest forested area and its extensive peatland forests, which are under the second-greatest rate of forest reduction in the face of timber extraction and agricultural expansion, such as by oil palm plantation (Edwards et al., 2012; FAO, 2015). As a part of REDD+ readiness in Indonesia, various policy-related and project-based pilot activities have been implemented (Dixon \& Challies, 2015; McNeill, 2015). Because these initiatives of project-level REDD+ under complex socioeconomic conditions will be common challenges in Indonesia, this study examined how identification of agents and drivers of deforestation through socioeconomic surveys can be utilized for instituting the REDD+ activities design in readiness phase. We examined this question through surveys conducted around GunungPalung National Park (GPNP) in Indonesia using the following steps: 1) recognize the actual deforestation situation around the study area through satellite imagery analysis, 2) identify drivers and agents of deforestation and their linkages with key socioeconomic characteristics through field surveying and statistical analysis, and 3) determine appropriate measures and their application level. After a description of the analyzed results, especially for 1) and 2), options for REDD+ readiness activities are proposed in the discussion session.

\section{Method}

\subsection{Study Area}

GunungPalung National Park (GPNP), which covers 90,000 hectares of conservation forest (hutankonservasi in Indonesian) designated in 1990 and proposed as a potential REDD+ area by the Ministry of Environment and Forestry (MoEF) in Indonesia, was selected as the research site. Currently, around 45,000 people, comprising various ethnic groups such as Malay, Dayak, Javanese, Bugis, Madura, and Chinese, live in 20 villages that share boundaries with GPNP and are located in two districts-Ketapang and Kayong Utara. Annual rainfall in 
Kayong Utara District was $2645 \mathrm{~mm}$ in 2013, with periods of reduced rainfall from January to March and August to October (BPS, 2014). Based on consultation with the GPNP office and after considering the extent of land cover changes determined through field observation and satellite image analysis, as described in the results, six villages from the 20 surrounding villages were selected for this study. In addition, through interviews with village representatives, it was assumed that ethnicity and geographic characteristics would be closely related with livelihoods and forest uses of the communities. Thus, two of the six villages, which have a relatively large variety of ethnic groups and higher utilization of forest resources, were selected from each of the western, eastern, and southern parts of the GPNP. These villages are Sedahan Jaya and Sejahtera in the western part, Sempurna and PangkalanTeluk in the eastern part, and RiamBerasap and LamanSatong in the southern part. Villages in the northern part of GPNP were excluded from the sample because communities in the area currently use few forest resources due to separation by a large river and are largely recruited by oil palm companies. Each village (desa), a minimum government unit, consisted of three to five sub-villages (dusun), which tend to have similar ethnic groups and cultures.

\subsection{Data Collection}

Necessary data for identifying the socioeconomic conditions in the six target villages were collected through questionnaire surveys as well as by semi-structured interviews as a part of the activities in the Indonesia-Japan Project for the Development of REDD+ Implementation Mechanism (IJ-REDD+), which is a technical cooperation project between the Japan International Cooperation Agency (JICA) and the Ministry of Environment and Forestry (MoEF) in Indonesia. The questionnaire surveys and semi-structured interviews were conducted by experienced local surveyors recommended by a local NGO after confirming survey skills and ethical consideration. Following semi-structured interview was done by Indonesian staff in the IJ-REDD+ project.

The questionnaire survey for the six villages was conducted by attempting to elicit quantitative information, such as types and amounts, within five main survey sections: basic information (family size and ethnicity), assets (livestock and land use), farming conditions (types of crops, productivity, location of farming), collection of non-timber forest products (NTFP; type of NTFP, amount, location of collection), and income structure (amount from on-farm and off-farm activities). These survey items were designed and selected by referring to previous socioeconomic-related surveys around the GPNP (Lawrence et al., 1998; Hiller et al., 2004; Zamzani, 2008). Households for the survey were selected by using a stratified sampling method, which extracts characteristics of various ethnic groups, farming types, and livelihood types by referring to village profile statistics. According to the stratified number of ethnic groups, farming types, and livelihood types in each village, sample households were selected with guidance from village leaders. From the six sample villages, 510 samples (18.7\%) were selected from about 2722 total households: 120 samples (20.0\%) in Sedahan Jaya, 70 samples (12.3\%) in Sejahtera, 80 samples (21.2\%) in Sempurna, 90 samples (26.4\%) in PangkalanTeluk, 60 samples (20.7\%) in RiamBerasap, and 90 samples (16.5\%) in LamanSatong (BPS, 2014). For each household survey, it took around two hours mostly in the afternoon or nigh time when villagers finished daily farm activity. After the questionnaire survey had been administered, semi-structured interviews, which aimed to obtain supplemental background information about farming practices and forest uses, were conducted for 10 randomly selected households in each village that engaged in farming and NTFP collection. These surveys and interviews were conducted from October 2014 to March 2015.

\subsection{Data Analysis Procedure}

At the beginning stage, the basic characteristics of the livelihoods and natural resource uses in the six sample villages were compared by means of the collected data. Then, statistical analysis was proceeded by using canonical discriminant analysis (CDA), analysis of variance (ANOVA), and principal component analysis (PCA) because it was desirable to obtain valuable information required to grasp the characteristics of each community. Whereas CDA and ANOVA are useful for finding a combination of features that separates multiple classes of objects, such as villages and ethnic groups, PCA, referring to previous studies (Soto \& Pintó, 2010; Valdivia et al., 2012; Jadin et al., 2013), can be utilized to identify key variables by reducing the various socioeconomic factors in a region. The statistical analysis was conducted by the following four steps: 1) confirm the characteristics of the national park users by comparing the engagement rate among villages and ethnic groups to identify tendencies of drivers and agents based on socioeconomic and geographic conditions, 2) conduct a CDA to explore 
the possibility of separating sample households by ethnic group and geographical location, 3) examine the PCA and draw a scatters map of sample households to extract the key characteristics for proposing an effective capacity building program for villagers' REDD+ activities, and 4) conduct an ANOVA to reveal the relationship between national park users and possession of farm land.

\subsection{Satellite Image Analysis}

In order to reveal the situation of deforestation in the six target villages around the GPNP, land cover changes in circular plots with a radius of five kilometers from the center of the sampled village or sub-village were calculated from remote sensing data (Figure 1). For the analysis, satellite imagery of a middle-resolution sensor (Landsat, in 2000 and 2013) was analyzed to compare land use and land-use changes within each plot. A ground truth survey was also conducted to verify the results of the land-use map derived from the Landsat data. Forest gardens, such as rubber and durian trees, utilized by local people were included in Secondary Dry Forest.

\section{Results}

\subsection{Land Cover Changes}

Deforestation rate for the target villages was calculated by analyzing the land use change between 2000 and 2013 (Table 1). The highest deforestation rate was exhibited in the villages in the east area, $50.2 \%$ in Sempurna and $49.3 \%$ in PangkalanTeluk. This deforestation was caused mainly by the development of oil palm plantation, which began around 2008 near the villages. Approximately half of the forest area outside the GPNP, which had not been designated as conservation (hutankonservasi) or protected (hutanlindung) forest by the MoEF, was logged and converted to oil palm plantation. The medium rate, 32.9\% - 36.1\%, of deforestation was seen in the villages in the south. This change also can be attributed largely to oil palm plantation initiated since 2008.

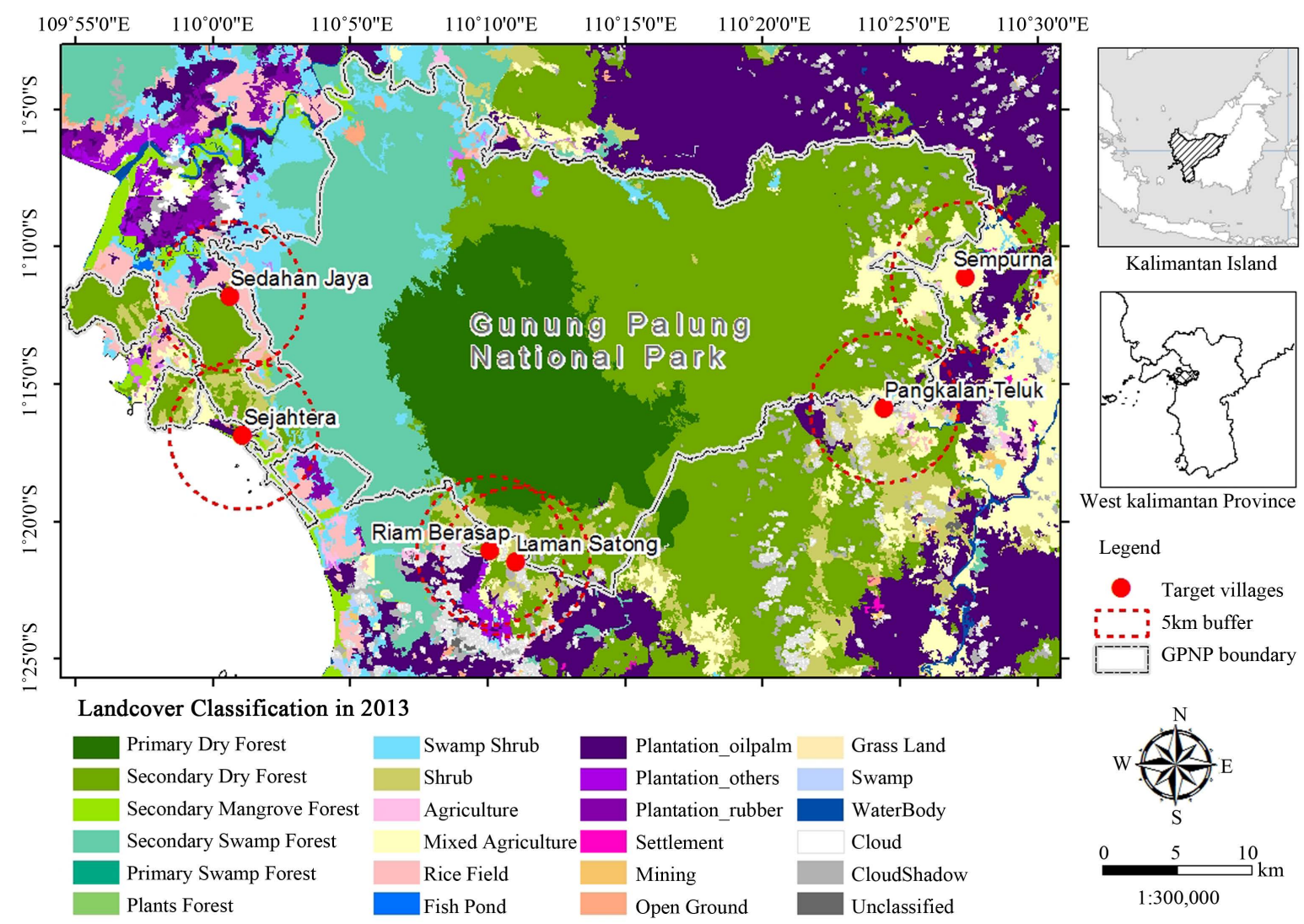

Figure 1. Circular plots with radius of five kilometers of the six target villages around the GPNP. 
Table 1. Changes of forest area and deforestation rate in the six target villages around the GPNP.

\begin{tabular}{ccccc}
\hline \multirow{2}{*}{ Area } & Village & \multicolumn{2}{c}{ Forest area $\left(1000 \mathrm{~km}^{2}\right)$} & Deforestation rate $(\%)$ \\
\cline { 3 - 4 } & & 2000 & 2013 & 0.0 \\
\multirow{2}{*}{ West } & Sedahan Jaya & 3.66 & 3.66 & 11.5 \\
& Sejahtera & 2.80 & 2.48 & 50.2 \\
\multirow{2}{*}{ East } & Sempurna & 5.40 & 2.69 & 49.3 \\
& Pangkalan Teluk & 7.95 & 4.04 & 35.1 \\
\hline \multirow{2}{*}{ South } & RiamBerasap & 5.11 & 3.31 & 32.9 \\
\hline
\end{tabular}

However, the change was not as high as that in the east because the villages are located near state forest, such as production forest (hutanproduksi), and the GPNP. The lowest deforestation rate occurred in the west area, $11.5 \%$ in Sejahtera and 0\% in Sedahan Jaya. Even though there is not yet any development of oil palm plantation around the area, people use the area for farming and as forest garden (kebunhutan). According to the village leader of Sedahan Jaya village, deforestation and degradation by people in the community might be accelerated due to increasing population and demand for forest resources and farming area. These risks can be estimated as potential drivers or underlying causes of deforestation commonly applicable to the study area.

\subsection{Overview of Socioeconomic Characteristics}

From the questionnaire survey, 19 socioeconomic attributes were prepared as a dataset for statistical analysis (Table 2). By comparing the means of number or volume for each socioeconomic attribute, features of the six sample villages could be summarized for main ethnic group, main income sources, and ways of using forest area in the national park (Table 3). In terms of ethnic groups, the Sedahan Jaya and Sejahtera villages consist of various ethnic groups, such as Malay, Javanese, Balinese, and Bugis, whereas the other villages are relatively dominated by a single ethnic group, Malay or Dayak. In all of the villages, but especially in Sedahan Jaya, paddy rice agriculture is the main farming activity. However, there is a significant difference in the annual amount of paddy production: 3.0 ton/ha in Sedahan Jaya compared with only 0.2 to 0.4 ton/ha in the other villages. The availability of sufficient water resources and irrigation facilities in Sedahan Jaya probably contributes to the larger amount of harvest. The number of households that cultivate vegetables and fruits in home gardens is higher in Sedahan Jaya and RiamBerasap. The main livestock is chicken, which is owned by almost half of the households in all sample villages. Ownership of cattle is less than $10 \%$, and swine are owned only in Sedahan Jaya and LamanSatong, where residents of Balinese and Dayak ethnicity are present. Such livestock graze mostly around houses within villages outside the national park. Regarding land use, uses of the forest area inside the national park for rice crop farming and forest gardens are especially higher in Sejahtera, Sedahan Jaya, and Sempurna, although this practice does occur in all villages. Whereas forest gardening in the national park consists of the planting of various NTFP, such as rubber, durian, and banana, among the natural trees, plantation outside of the national park is generally unitary rubber or wood production. According to the interviews conducted in Sempurna village, the boundary of the national park was demarcated without sufficient consideration to traditional uses of forest area for rice and rubber cropping prior to foundation of the GPNP. For this reason, approximately half of the households in Sempurna village have conducted activities inside the national park. Collection of NTFP, mainly firewood and durians, occurs mostly inside the national park because of the limited forest resources around the villages. According to the interview survey, there are customary user rights for durian trees. In order to participate in collecting durian fruits from the ground, people do minimum management such as weeding around the trees. Firewood for cooking is collected by more than half of the households in all of the sample villages. For income structure, on-farm activities are the main source of income in Sedahan Jaya and Sempurna, whereas off-farm income has a higher mean in the other four villages. Especially, the mean income from on-farm activities is quite low in RiamBerasap. In most villages, except for Sedahan Jaya and Sejahtera in the west area, about $30 \%$ to $50 \%$ of the sampled households acquire their income by working on oil palm plantations. 
Table 2. Socioeconomic attributes and units used in the statistical analysis.

\begin{tabular}{|c|c|c|}
\hline \multicolumn{2}{|c|}{ Socioeconomic Attributes } & Unit \\
\hline \multirow{2}{*}{ Agricultural Production } & Rice cropping & Ton/year \\
\hline & Home garden & Kg/year \\
\hline \multirow{3}{*}{ Possession of Livestock } & Cow & Head \\
\hline & Pig & Head \\
\hline & Chicken & Head \\
\hline \multirow{4}{*}{ Land Use } & Farm inside NP & $1000 \mathrm{~m}^{2}$ \\
\hline & Farm outside NP & $1000 \mathrm{~m}^{2}$ \\
\hline & Forest garden inside NP & $1000 \mathrm{~m}^{2}$ \\
\hline & Plantation outside NP & $1000 \mathrm{~m}^{2}$ \\
\hline \multirow{2}{*}{ NTFP collection } & Fuelwood & Bundle/year \\
\hline & Durian & $100 \mathrm{~kg} /$ year \\
\hline \multirow{8}{*}{ Income } & Paddy rice & 100,000 Rupiah/year \\
\hline & Vegetables & 100,000 Rupiah/year \\
\hline & NTFP (excluding rubber) & 100,000 Rupiah/year \\
\hline & Rubber plantation & 100,000 Rupiah/year \\
\hline & Total on-farm activities & 100,000 Rupiah/year \\
\hline & Labor in oil palm plantation & 100,000 Rupiah/year \\
\hline & Employment salary & 100,000 Rupiah/year \\
\hline & Total off-farm activities & 100,000 Rupiah/year \\
\hline
\end{tabular}

Table 3. Main socioeconomic features of the six sample villages.

\begin{tabular}{|c|c|c|c|c|c|c|}
\hline Area & Village & $\begin{array}{c}\text { Total } \\
\text { Households }\end{array}$ & $\begin{array}{c}\text { No. of } \\
\text { Sample } \\
\text { Households }\end{array}$ & $\begin{array}{l}\text { Main Ethnic } \\
\text { Group }\end{array}$ & Main Income & $\begin{array}{c}\text { Use of Forest Area in the } \\
\text { National Park }\end{array}$ \\
\hline \multirow[t]{2}{*}{ West } & Sedahan Jaya & 601 & 120 & $\begin{array}{l}\text { Malay, } \\
\text { Balinese, } \\
\text { Javanese }\end{array}$ & Agriculture & $\begin{array}{l}\text { Moderate for NTFP } \\
\text { collection and paddy }\end{array}$ \\
\hline & Sejahtera & 568 & 70 & Malay, Bugis & $\begin{array}{l}\text { Employment, } \\
\text { Agriculture }\end{array}$ & $\begin{array}{l}\text { Moderate for durian } \\
\text { collection }\end{array}$ \\
\hline \multirow{2}{*}{ East } & Sempurna & 377 & 80 & Malay & $\begin{array}{l}\text { Rubber, Employment, } \\
\text { Oil Palm }\end{array}$ & $\begin{array}{l}\text { High for rubber } \\
\text { plantation, paddy and } \\
\text { durian collection }\end{array}$ \\
\hline & $\begin{array}{l}\text { Pangkalan } \\
\text { Teluk }\end{array}$ & 341 & 90 & Malay & $\begin{array}{l}\text { Employment, Oil } \\
\text { Palm, Agriculture }\end{array}$ & Low \\
\hline \multirow{2}{*}{ South } & RiamBerasap & 290 & 60 & Malay & $\begin{array}{l}\text { Employment, Oil } \\
\text { Palm }\end{array}$ & Low \\
\hline & Laman Satong & 545 & 90 & Dayak, Malay & $\begin{array}{l}\text { Oil Palm, } \\
\text { Employment }\end{array}$ & $\begin{array}{c}\text { Moderate for NTFP } \\
\text { collection and up-land rice }\end{array}$ \\
\hline
\end{tabular}

\subsection{Features of Forest Users}

In order to understand the actual situation of deforestation agents and drivers around the study area, the percentage of households that use sites inside the national park for farming and forest gardening was examined by village (Figure 2). For each village, the percentage of users is shown with the classification of Malay or non-Malay. Even though users were identified in almost all villages, their number is remarkably high in Sempurna village, 

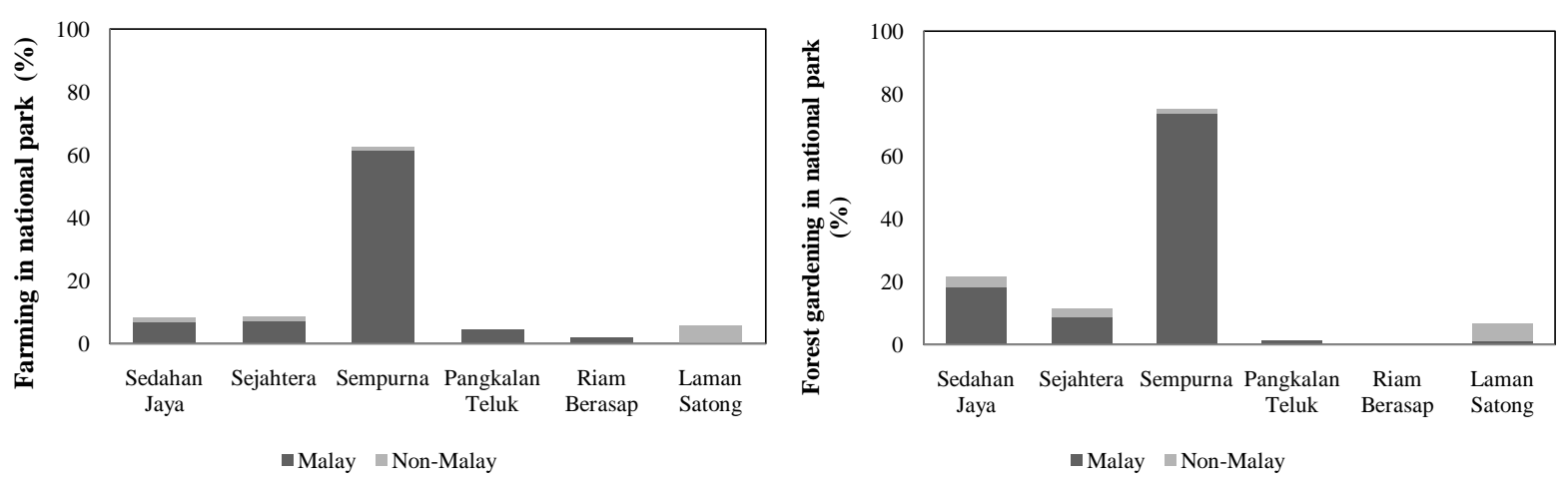

Figure 2. Percentage of households using sites inside the national park for farming (left) and forest gardening (right) by village.

where more than $60 \%$ of households engage in farming or forest gardening inside the national park. This trend in Sempurna corresponds with the results of the interview survey and the land cover changes (Table 1). Thus, in the case of Sempurna, not only oil palm plantation but also use of the national park can be estimated as deforestation drivers in the east area. In the west region, Sedahan Jaya and Sejahtera, approximately $10 \%$ to $20 \%$ of households use sites inside the national park. The users are mostly Malay residents, except for in LamanSatong village where a majority of the residents are members of the Dayak group. When these data are compared with deforestation rate (Table 1), the national park users in the west and south areas seem to have smaller impact on deforestation compared with those in the east. This implies that the situation of deforestation drivers and agents is varied among different areas and villages.

For obtaining additional details about the condition of deforestation drivers, especially in Sempurna, the engagement rate of rubber plantation activity, either within or outside of the national park, was compared among the sample villages (Figure 3). The rate was highest in Sempurna, followed by PangkalanTeluk, which are both in the east area. As shown by the ethnic groupings in the figure, non-Malay people, such as Bugis and Dayak residents, also engage in rubber plantation in Sejahtera and LamanSatong, whereas it is conducted entirely by Malay households in the eastern villages. Additionally, the percentage of households possessing plantation sites outside of the national park is illustrated by village in Figure 4. The rate is higher in PangkalanTeluk, Sejagtera, and LamanSatong, which corresponds with the result of engagement rate for rubber plantation (Figure 3). This means that rubber plantation activities must be conducted outside of the national park in these three villages, which may have sufficient land for plantation inside the village. However, only around $10 \%$ of households in Sempurna conduct rubber plantation outside of the national park, which is remarkably lower than the actual engagement rate of around 90\% (Figure 3). When this result is compared with the result of engagement of forest gardening inside the national park (Figure 2), it is apparent that the rubber cultivation activities of Sempurna village are conducted mostly inside the national park as relatively intensive forest gardening activity.

From these results, the percentages of households using sites inside the national park for farming or forest gardening are highly varied among the villages, although such activities occur in all villages. Especially, those uses in Sempurna village have relatively larger number than in the other villages and could be mostly engaged in rubber tapping activity as intensive forest gardening. It is a relevant park management issue, as described above, that traditional uses of farming and rubber cropping were not reflected in the boundary demarcation of the national park and that a mismatching of recognition by villagers in Sempurna has continued to present. Even though similar traditional uses of the forest was mentioned for Sedahan Jaya, the practice there could be more extensive agroforestry of growing fruits and NTFP species compared with that in Sempurna. With regard to ethnic group, Malay people seem to have larger rates of engagement in rubber plantation.

\subsection{Examination of Ethnic Characteristics}

In order to examine features for classifying ethnic groups in sample households, a CDA was conducted for the five main ethnic groups, Malay, Dayak, Javanese, Balinese, and Bugis, in the study area. For the CDA, all socioeconomic attributes were used and the process was continued by replacing factors until the highest discrimination rate was attained. Finally, the attributes were narrowed down to eight variables related with land use and 


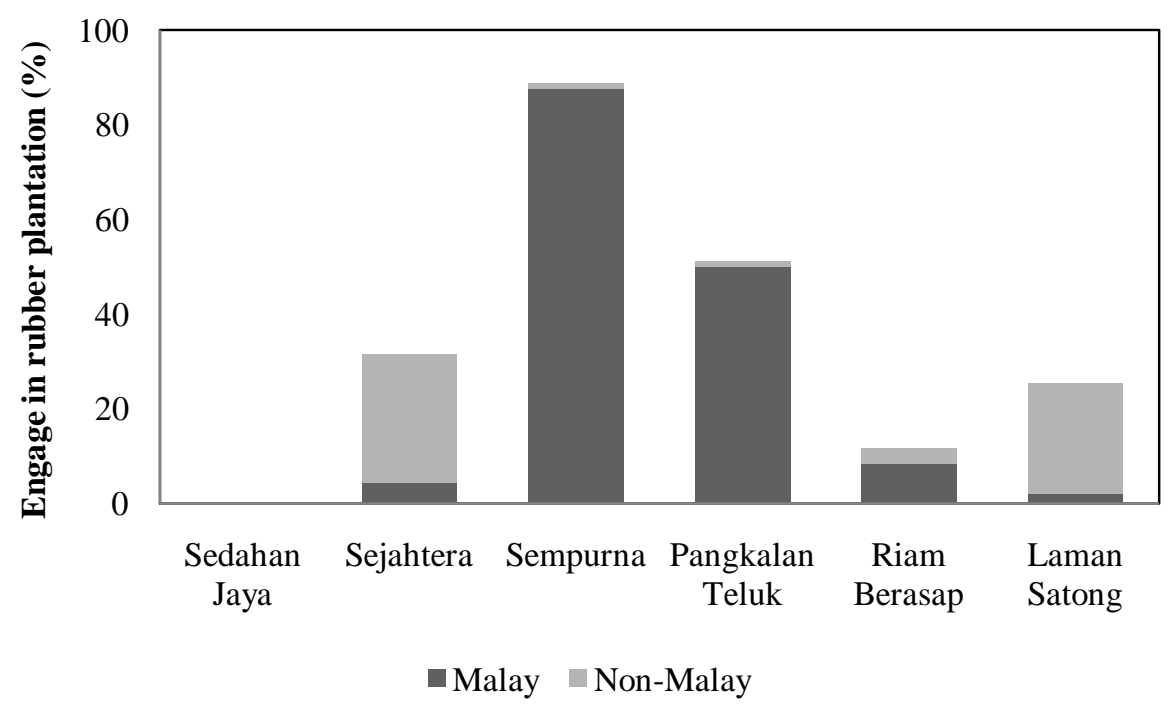

Figure 3. Percentage of households engaged in rubber plantation by village.

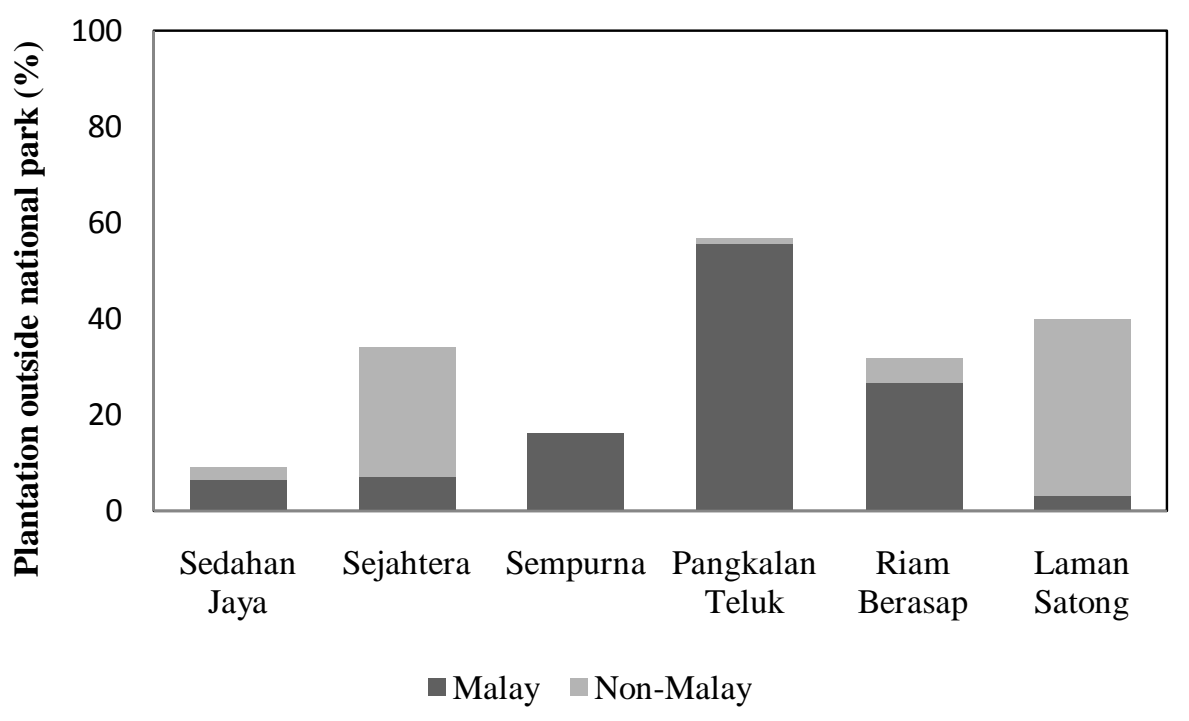

Figure 4. Percentage of households possessing plantation sites outside of the national park.

income that were closely related to the land use patterns. The extracted result, a $60.6 \%$ overall correct classification, showed that the socioeconomic characteristics of the sample households could not be discriminated well by ethnic group (Table 4). When examining the details of each ethnic group, Malay people, who occupy the majority of the samples, exhibit higher varieties of characteristics compared with other ethnic groups because they are classified correctly not only as Malay (63.4\%) but also as Dayak (25.0\%), Balinese (6.1\%), and Javanese (5.2\%). Some Dayak groups are also classified as Malay (35.3 \%). From the results, it was assumed that characteristics of Malay and Dayak would be similar when compared with other groups. These results show that each village would not be characterized with one ethnic group even though Malay or Dayak people are dominant in the six target villages. Thus, the use of ethnic group is not appropriate for explaining the socioeconomic characteristics of sample households or assigning agents in the area. During the survey, some sample households noted that they had converted their ethnic identity from Balinese or Dayak to Malay due to a change of religious faith from Hindu or Christianity to Islam, which was also observed in previous studies (Nagata, 1974; Reid, 2001). The trend of ethnic homogenization as Islamic Malays will continue even though cultures and customs may vary based on original ethnicity. 
Table 4. Results of discriminant analysis by five ethnic groups.

\begin{tabular}{|c|c|c|c|c|c|c|c|}
\hline \multirow{2}{*}{\multicolumn{2}{|c|}{ Group }} & \multicolumn{5}{|c|}{ Predicted group } & \multirow{2}{*}{ Total } \\
\hline & & Malay & Dayak & Javanese & Balinese & Bugis & \\
\hline \multirow{10}{*}{$\begin{array}{c}\text { Original } \\
\text { count }\end{array}$} & \multirow{2}{*}{ Malay } & 208 & 82 & 17 & 20 & 1 & 328 \\
\hline & & (63.4\%) & $(25.0 \%)$ & $(5.2 \%)$ & $(6.1 \%)$ & $(0.3 \%)$ & $(100 \%)$ \\
\hline & \multirow{2}{*}{ Dayak } & 30 & 55 & 0 & 0 & 0 & 85 \\
\hline & & (35.3\%) & $(64.7 \%)$ & $(0 \%)$ & $(0 \%)$ & $(0 \%)$ & $(100 \%)$ \\
\hline & \multirow{2}{*}{ Javanese } & 10 & 4 & 12 & 7 & 0 & 33 \\
\hline & & (30.3\%) & (12.1\%) & (36.4\%) & $(21.2 \%)$ & $(0 \%)$ & $(100 \%)$ \\
\hline & \multirow{2}{*}{ Balinese } & 1 & 1 & 4 & 21 & 0 & 27 \\
\hline & & (3.7\%) & $(3.7 \%)$ & (14.8\%) & (77.8\%) & $(0 \%)$ & $(100 \%)$ \\
\hline & \multirow{2}{*}{ Bugis } & 16 & 2 & 0 & 0 & 4 & 22 \\
\hline & & (72.7\%) & (9.1\%) & $(0 \%)$ & $(0 \%)$ & $(18.2 \%)$ & $(100 \%)$ \\
\hline
\end{tabular}

Overall rate of correct classification: $60.6 \%$.

\subsection{Examination of Geographic Characteristics}

To explore the geographic features of the areas, a CDA was conducted by using and replacing all socioeconomic attributes until the highest classification rate (70.2\%) was acquired (Table 5). The results showed a higher rate by areas than that obtained by ethnic groups (Table 4), which could imply that socioeconomic characteristics are more appropriate for discriminating geographic differences. The south area consisting of RiamBerasap and LamanSatong showed the highest correct classification (79.3\%), whereas the east area including Sempurna and PangkalanTeluk showed the lowest (65.9\%). The insufficient discrimination in the east might be attributable to the remarkably high rate of the users inside the national park in Sempurna, which causes different characteristics compared with PangkalanTeluk even in the same (east) area. This implies that use of national park area should be classified not only by geographic location but also by socioeconomic features of the sample households.

Based on the implications of the CDA by area, a further CDA was conducted by extracting Sempurna as one group and by combining PangkalanTeluk and the villages in the south as the same socioeconomic type: 1) main livelihood from agriculture, the two villages in the west; 2) higher use of the national park area, Sempurna; and 3) main income from oil palm plantation, the two villages in the south and PangkalanTeluk in the east. The overall correct classification rate of 74.9\% (Table 6) was higher than that of the result by area, 70.2\% (Table 5). The rate of correct classification for type B, Sempurna, is a clearly higher rate (76.3\%) than that obtained by combining it with PangkalanTeluk, as in Table 5 (65.9\%). Even type 3 shows a slightly higher rate (80.8\%) by adding PangkalanTeluk when compared with the result for the south area (79.3\%; Table 5). For the analysis, eight variables of agricultural production, land use, and income were used, and a structure matrix with center of gravity was extracted (Table 7). The center of gravity in function 1 corresponds with features of each socioeconomic type such that main livelihood in agriculture (Type 1) tends to be high in "production from rice cropping" whereas users of national park (Type 2) tends to be high in "income from rubber." Looking at function 2, villages with their main income from oil palm plantation (Type 3) show a negative value in the center of gravity as well as in the structure matrix.

From these results, classifying the sample households by key socioeconomic type was found to be more appropriate compared with using ethnic group or geographic location in the case of the study area around GPNP. In addition to agricultural practices and forest uses, off-farm income activity by laboring for oil palm companies exhibits as one of the main types. Those households might be recognized as a newly emerged agent since their accepting of investment by oil palm plantations by converting their farm land and forest areas.

\subsection{Extraction of Key Characteristics in the Regions}

To assist the results of the CDA and to identify possible agent groups impacting forest resources and their relationships with socioeconomic characteristics, a PCA with economic variables was applied to the whole sample households in the six villages. Prior to being subjected to the PCA, the units of quantitative variables were 
Table 5. Results of canonical discriminant analysis by the three areas.

\begin{tabular}{|c|c|c|c|c|c|}
\hline \multirow{2}{*}{\multicolumn{2}{|c|}{ Area }} & \multicolumn{3}{|c|}{ Predicted area } & \multirow{2}{*}{ Total } \\
\hline & & West & East & South & \\
\hline \multirow{6}{*}{ Original count } & \multirow{2}{*}{ West } & 127 & 10 & 53 & 190 \\
\hline & & (66.8\%) & (5.3\%) & (27.9\%) & $(100 \%)$ \\
\hline & \multirow{2}{*}{ East } & 10 & 112 & 48 & 170 \\
\hline & & $(5.9 \%)$ & (65.9\%) & $(28.2 \%)$ & $(100 \%)$ \\
\hline & \multirow{2}{*}{ South } & 11 & 20 & 119 & 150 \\
\hline & & $(7.3 \%)$ & (13.3\%) & (79.3\%) & $(100 \%)$ \\
\hline
\end{tabular}

Overall rate of correct classification: $70.2 \%$.

Table 6. Results of canonical discriminant analysis by the three socioeconomic types.

\begin{tabular}{|c|c|c|c|c|c|}
\hline \multirow{2}{*}{\multicolumn{2}{|c|}{ Type }} & \multicolumn{3}{|c|}{ Predicted type } & \multirow{2}{*}{ Total } \\
\hline & & A & B & C & \\
\hline \multirow{6}{*}{ Original count } & \multirow{2}{*}{ A } & 127 & 3 & 60 & 130 \\
\hline & & (66.8\%) & $(1.6 \%)$ & (31.6\%) & $(100 \%)$ \\
\hline & \multirow{2}{*}{ B } & 0 & 61 & 19 & 80 \\
\hline & & $(0.0 \%)$ & (76.3\%) & $(23.8 \%)$ & $(100 \%)$ \\
\hline & \multirow{2}{*}{$\mathrm{C}$} & 20 & 26 & 194 & 240 \\
\hline & & $(8.3 \%)$ & $(10.8 \%)$ & (80.8\%) & (100\%) \\
\hline
\end{tabular}

Overall rate of correct classification: 74.9\%. A: Main livelihood in agriculture (Sedahan Jaya, Sejahtera). B: High use of National Park area (Sempurna). C: Main income from oil palm plantation (Pangkalan Teluk, Riam Berasap, Laman Satong).

Table 7. Structure matrix and center of gravity from canonical discriminant analysis by the three socioeconomic type.

\begin{tabular}{ccc} 
Variable & \multicolumn{2}{c}{ Function } \\
\cline { 2 - 3 } Production from rice cropping & 1 & 2 \\
Farm area inside National Park & -0.49 & 0.53 \\
Farm area outside National Park & 0.37 & 0.45 \\
Forest garden inside National Park & -0.04 & 0.04 \\
Plantation outside National Park & 0.42 & 0.55 \\
Income from NTFP (excluding rubber) & -0.09 & 0.09 \\
Income from rubber & -0.01 & 0.05 \\
Income from oil palm plantation & 0.57 & 0.30 \\
Type A & 0.26 & -0.59 \\
Type B & -1.10 & 0.49 \\
Type C & 1.93 & 0.91 \\
\hline
\end{tabular}

standardized (Table 2). The PCA extracted four principle components (PCs), which accounted for $71.8 \%$ of the total variance (Table 8). For the analysis, eight independent variables that exhibited characteristics of agents were selected from the dataset. It can be inferred that these variables are key features showing the socioeconomic characteristics in this study area because these mostly match those used in the CDA (Table 7). 
Table 8. Results of principal component analysis for households in all six villages.

\begin{tabular}{ccccc}
\hline Variable & \multicolumn{3}{c}{ Principal Component (PC) } \\
\cline { 2 - 5 } & 1 & 2 & 3 & 4 \\
\hline Production from home garden & 0.501 & 0.106 & 0.130 & 0.034 \\
Farm area inside National Park & -0.053 & 0.449 & -0.077 & -0.169 \\
Forest garden inside National Park & -0.089 & 0.455 & -0.026 & -0.168 \\
Farming area outside National Park & -0.013 & 0.013 & -0.020 & 0.885 \\
Income from rice cultivation & 0.081 & -0.091 & -0.639 & -0.139 \\
Income from NTFP (excluding rubber) & 0.505 & 0.121 & 0.063 & 0.002 \\
Income from rubber & -0.125 & 0.400 & 0.084 & 0.258 \\
Income from oil palm company & -0.069 & -0.111 & 0.600 & -0.192 \\
\% variance & 23.0 & 20.3 & 15.6 & 13.0 \\
\hline
\end{tabular}

With regard to the extracted principal components (PCs), PC 1, explaining $23.0 \%$ of the variance, can be interpreted as separating households by main cropping type such as by NTFP collection with a positive value and commercial crops, rubber, and oil palm with negative values (Table 8). PC 2 makes it possible to identify households dependent on forest area, mainly inside the national park, for farming and agroforestry with a positive value. PC 3 helps to highlight households that conduct on-farm and off-farm activities, and PC 4 seems to emphasize the legality of land use as farming outside the national park has a high positive value while activities inside the national park have relatively high negative values. These implications from each PC, especially those of PC 1, PC 2, and PC 3, match with the main socioeconomic types in the CDA (Table 6): agricultural activity, use of the national park, and off-farm activities.

To explore additional details about legal land use, as deduced by PC 4 (Table 8), the engagement rate of farming activities outside the national park was examined (Figure 5). The result clearly shows that Sempurna has a value that is remarkably lower than the others, less than $20 \%$ of households, whereas the other villages generally exhibit a $50 \%-60 \%$ proportion of households using farm land outside of the national park. In order to examine the factor of possessing farm land outside of the national park, an ANOVA was conducted to explore the differences between non-immigrants and immigrants since 1990. The result of the ANOVA did not exhibit significant differences in the statistics, $F(1,508)=3.86, p=0.44$. This shows that legal land possession, farming in an area outside the national park, is not related with customary tenure or land ownership. It can also be seen that the proportion of Malay residents in Sedahan Jaya is not higher than that of non-Malay residents in engagement in farming outside of the national park (Figure 5), whereas a majority of the users of forest inside the national park were Malay (Figure 2). From these results, it can be deduced that such features of land tenure or assets have no clear linkage with ethnicity or time from immigration, but can be more strongly related with park management and lack of farmland, as observed in Sempurna village, which can be recognized as underlying causes of the higher rate of conducting activities inside the national park area.

\subsection{Identification of REDD+ Activities through Scatters Figures}

To explore appropriate REDD+ measures with priority targeting agents, scatter plot diagrams (Figure 6) were prepared by using the extracted variables and their PC factor scores for each PC in Table 8. Each dot in the diagram shows sample households and different symbols are used for the different socioeconomic types: A) main livelihood in agriculture, B) high use of the national park area, and C) main income from oil palm plantation, supporting the results of the CDA (Table 6). Contrasting PC 1 (main cropping type such as NTFP with a positive value and rubber with a negative value) as the X-axis with PC 2 (use of the national park with a positive value) as the Y-axis, the characteristics of the sample households can be separated by quadrant by main livelihoods and forest uses: quadrant 1) conducting forest gardening or home gardening inside or outside of the national park; quadrant 2) rubber tapping mainly inside the national park; quadrant 3) obtaining income by working for an oil palm company; and quadrant 4) main livelihood from rice cropping outside of the national park area. The 


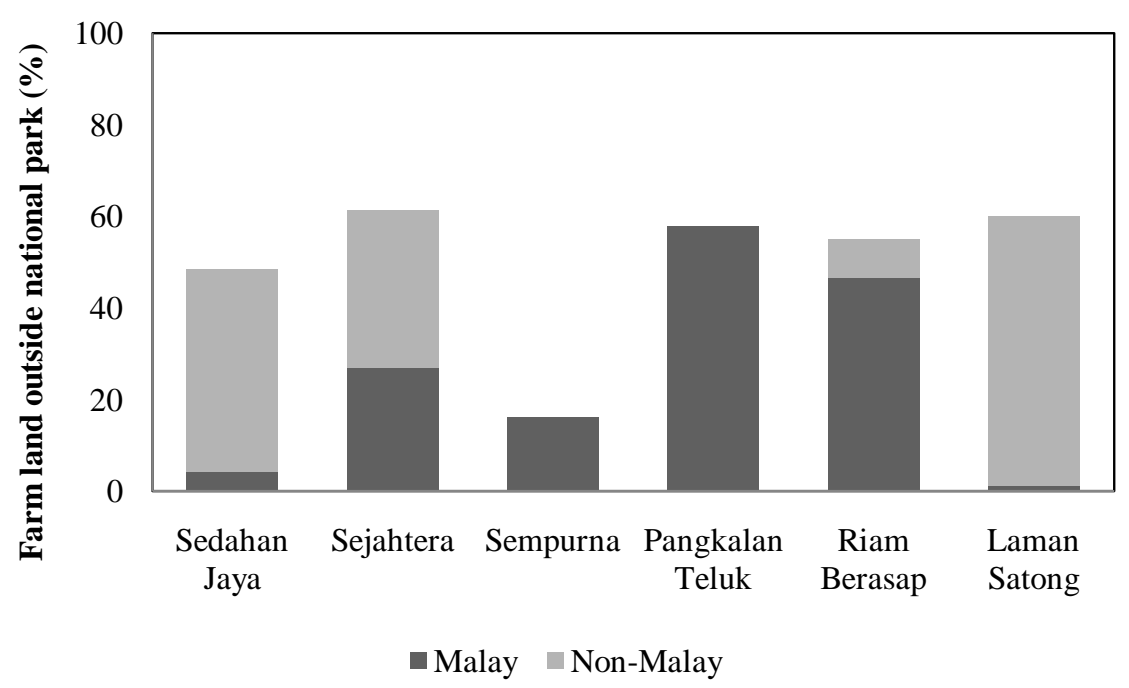

Figure 5. Percentage of households possessing farm land outside of the national park.

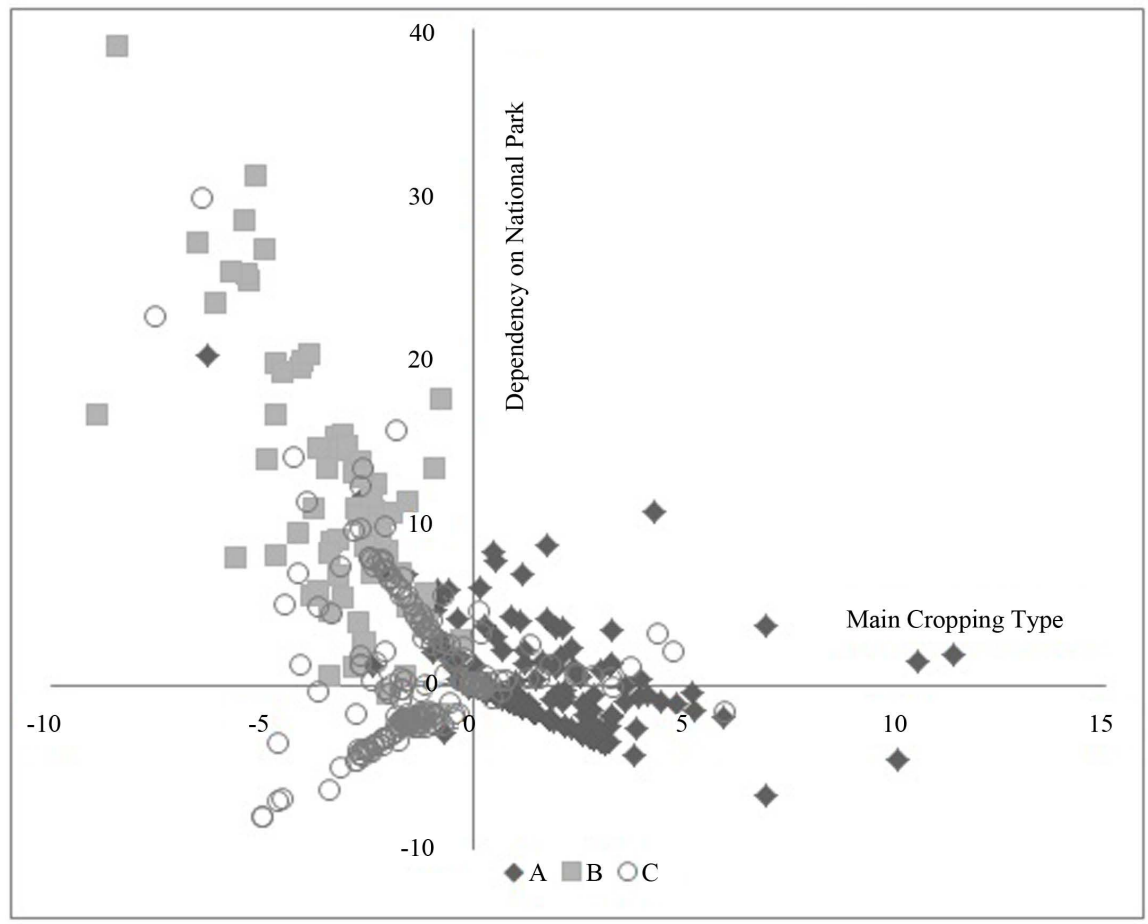

Figure 6. Distribution (factor scores) of households in the six villages on two principle components (PCs) by socioeconomic type. PC 1 (main cropping type) is used as the $\mathrm{X}$-axis, and PC 2 (dependency on national park) is used as the Y-axis.

households in quadrant 2 are recognized as a main agent group of deforestation and degradation because their activities are related with intensive use of sites inside the national park.

Examining the socioeconomic types shown by the symbols, the characteristics in each quadrant mostly match the socioeconomic type, especially for Type A (quadrants 1 and 4) and Type C (quadrant 3). However, there seems to be a mixture of the three socioeconomic types in quadrant 2, a main agent of deforestation in the national park, even though the majority is occupied by Type B. This implies that the agents and drivers are diverse in a geographic location and not always identified as a set in an area. Similar trends of mixing of the socioeconomic types are seen even in scatters when using the other PCs. 


\section{Discussion}

\subsection{Identification of Agents and Drivers by Combining Methods}

In this study, identification of deforestation agents and drivers was examined by combining satellite imaginary and socioeconomic surveying. By using satellite imagery, deforestation area could be identified at the macro level by historical land cover changes, such as conversion of forest area to oil palm plantation in the east and south areas of the study area (Table 1). For further detailed identification, the use of socioeconomic surveying with statistical analyses was shown to be effective. Statistical analysis by CDA could classify the agents effectively by geographic location but not by ethnic group (Table 4 and Table 5). Further CDA showed that socioeconomic type was even more appropriate for identifying sample households as types of agents (Table 6). By conducting both CDA and PCA, it became possible to understand that there are various agents, multi-layered drivers, and underlying causes in even the same village or location. These results highlight the effectiveness of combining several methods such as satellite imagery and socioeconomic surveying with statistical analysis for appropriate identification of deforestation agents and drivers.

With regard to underlying causes, the PCA result (Table 8) and the ANOVA implied that not possessing secured farm land, especially in Sempurna, could be an underlying cause of a related deforestation driver, such as farming and forest gardening inside the national park. The interviews revealed that such uses are related with park management as the peoples' traditional land use pattern was not fully considered in boundary demarcation when the national park enacted. Similar issues such as a lack of farm land and unclear boundaries were also pointed out in other villages. The current uses of the national park may be accelerated and expanded if appropriate measures for increasing population and insufficient farm land are not taken. The same concerns can be applied in other areas that have lost farm land and surrounding forest resources by conversion to oil palm plantation.

Drawing scatter diagrams by use of PCA results can assist clear recognition of interactions among agents, drivers, and underlying causes. When contrasting PC 1 and PC 2, various socioeconomic types were seen in a quadrant, such as in quadrant 2, which represents intensive use of the national park area (Figure 6). Such a distribution suggests that an identified agent and driver may not always match in a given area. Rather, various agents associated with multiple socioeconomic activities, or drivers, can impact the land cover in an area. Under such conditions, decomposing into agents, drivers, and underlying causes, as proposed in the VCS methodology (VCS, 2012), can aid recognition of interactions and target levels for providing activities. The target level in this study area should be designated for households by socioeconomic type rather than by ethnic group or geographic location as various agents and drivers exist in an area, as shown in the scatters (Figure 6).

\subsection{Implications for Designing REDD+ Readiness Activities}

By utilizing PCA with the scatters (Figure 6), it is possible to consider and design appropriate strategies for REDD+ readiness. The distribution of main agents with socioeconomic type can be summarized as a conceptual diagram (Figure 7). The main agents can be classified by quadrant: 1 ) households that conduct home gardening or NTFP collection (mixture of Types A and B), 2) users of sites inside the national park mainly for rubber production, 3) main livelihood in rice cropping (Type A), and 4) receiving income from off-farm activities such as oil palm plantation. In this case, a priority target group of measures should be the households that conduct rubber plantation in the national park area, type B in quadrant 2. Under the unstable international market price of rubber, the motivation for expanding plantation areas into forest areas will persist without appropriate countermeasures. As means for addressing those agents, shifting those households in quadrant 2 to other quadrants, especially quadrants 1 and 4 , can be targeted. Then, a final goal would be to settle within quadrant 3 , those who conduct off-farm activities without using national park area. Based on the targeting quadrant and the terms, potential activities can be classified into the following three activity types.

Activity type 1: Potential activities with short-terms goals to introduce alternative on-farm incomes such as growing and processing marketable horticultural crops such as vegetables and NTFPs that can be grown on existing farm or residential area with minimum usage of forest area. Additionally, measures for suppressing pressure on forest areas need to be taken by establishing forest utilization rules and monitoring as a process of collaborative management and safeguards with community and other stakeholders.

Activity type 2: Potential activities that could be conducted as medium-term interventions, such as technical 


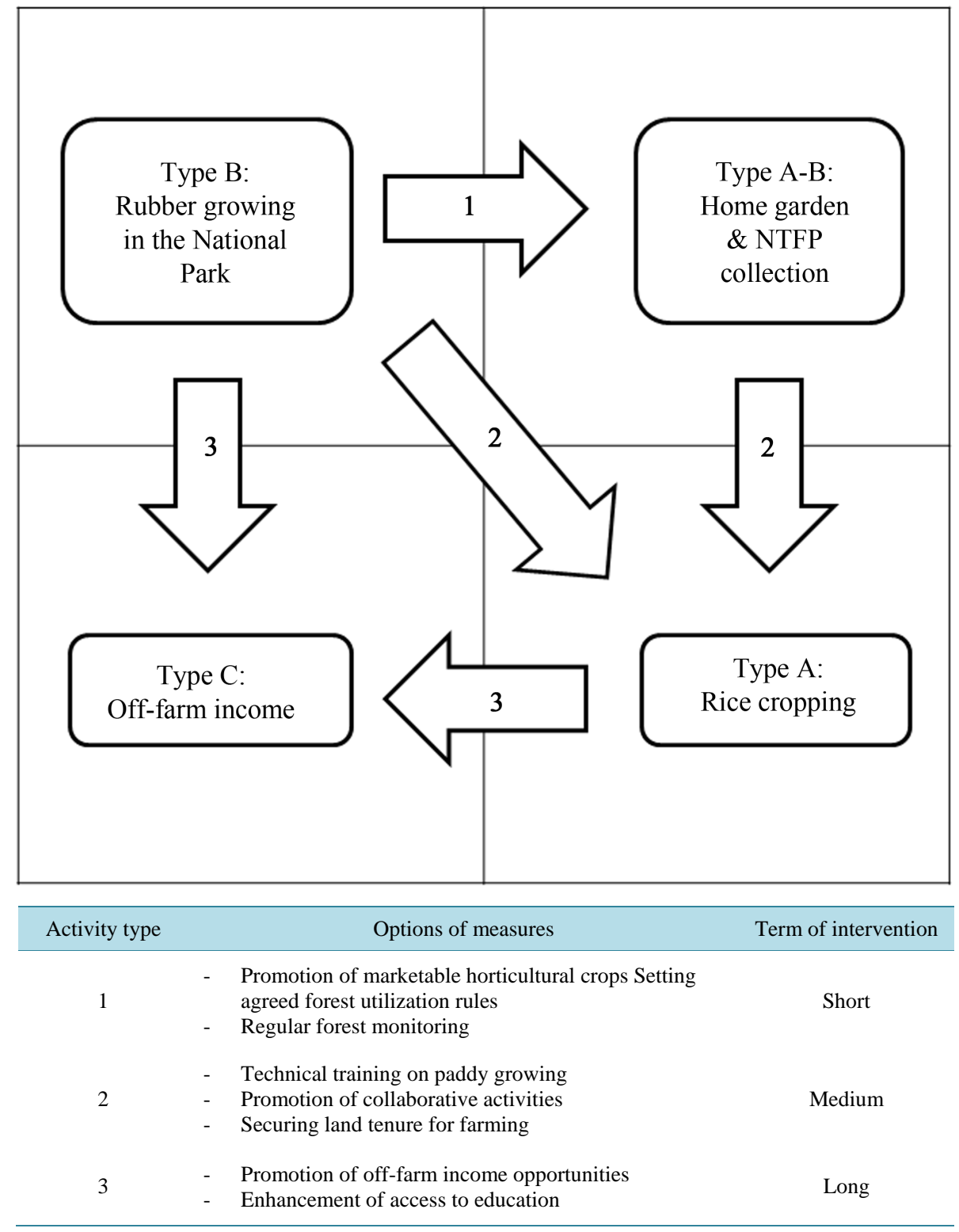

Figure 7. Types of potential activities for each agent identified through the PCA in the study area.

training on paddy farming, collaborative activities for irrigation management, and cooperative marketing. By increasing agricultural productivity through enhanced skills, mitigation of forest use can be expected. However, the issue of insufficient farm land needs to be considered as a common issue in the study area. Thus, securing sufficient farm land in villages is a prerequisite for achieving sustainable land and forest management in the area.

Activity type 3: Promotion of off-farm income activities as a long-term approach by considering underlying causes such as population increase and insufficient land. Although the existing oil palm plantations provide a means of cash income, the distribution in the scatter diagrams shows that some of residents still rely on farming activities as the plantation owners cannot hire all households in the region. Additionally, most of the people hired for work at the oil palm plantations also continue agricultural activities as part-time farmers. Thus, it would be more appropriate to introduce the aforementioned Type 1 to 2 activities as well as opportunities for off-farm income. Moreover, facilitating access to basic education can be critically important for enhancing capability for acquiring additional options and opportunities of employment and means of income (Sen, 2001). 
In addition to the potential activities mentioned above, political approaches for solving issues pertaining to insufficient farm land need to be considered as a measures for addressing underlying causes. To achieve sustainable forest management and REDD+, such efforts toward underlying causes and potential agents through appropriate identification of socioeconomic characteristics would also be essential in the readiness phase (Pasgaard, 2013; Salvini et al., 2014). At the same time, flexible decision-making and implementation are desirable in the process as socioeconomic conditions are diverse and may transform in accordance with development activities and related policies (Agung et al., 2014; Minang et al., 2014). Additionally, it critical to consider features of various agents with plural identities by developing and providing multiple measures (Sen, 1992). Thus, readiness activities such as capacity building and institutional arrangement need to be conducted by targeting various stakeholders such as community, local government, and private sector at multiple levels.

\section{Conclusion}

To examine how identification of deforestation agents and drivers could be useful for instituting REDD+ design in the readiness phase, satellite imagery analysis and socioeconomic surveying were conducted in six sample villages around the GPNP. After recognizing the deforestation situation with the remote sensing analysis, identification of deforestation agents and drivers was examined by statistical analysis using the dataset from the socioeconomic survey. The results revealed that there are various deforestation agents and drivers in the study area and that sample households can be discriminated more clearly by socioeconomic type than by ethnic group or geographical location. An examination of the classifying of various agents by using scatters diagrams from the PCA result implied that the agents and drivers identified do not always match in an area. Rather, various agents associated with multiple socioeconomic activities and drivers can impact the forest and land cover in an area. To implement REDD+ activities with sustainable forest management under such conditions, decomposing into agents and drivers as suggested in the VCS methodology will be important for their appropriate identification. Based on such identification and consideration of the socioeconomic situation, REDD+ readiness activities with appropriate level of application that consider various socioeconomic types and underlying causes can be conducted, as discussed in the case of the study area. When applying for REDD+ at the national or sub-national scale, a number of deforestation agents and drivers will be identified to address the broader area. To select appropriate targets and activities by establishing priorities, the methods for integrating various variables as the primary components in a PCA examined in this study can be utilized. Even though the possibility of a general approach for proposing REDD+ readiness activities was established from this case study in the GPNP, further examination including other forest areas will be needed for application in a more extensive area.

\section{Acknowledgements}

We acknowledge support from the Japan International Cooperation (JICA) and Ministry of Forestry and Environment for the Indonesia-Japan project for the Development of the REDD+ Implementation Mechanism (IJREDD+); we also received technical facilitation and cooperation from the Tanjungpura University in Indonesia. We would also like to thank the staff and consultants in the GunungPalung National Park office and IJ-REDD+ project for supporting our survey in the field. Those organizations and individuals responsible for primary data collection bear no responsibility for the analysis and interpretations presented herein.

\section{References}

Agung, P., Galudra, G., Van Noordwijk, M., \& Maryani, R. (2014). Reform or Reversal: The Impact of REDD+ Readiness on Forest Governance in Indonesia. Climate Policy, 14, 748-768. http://dx.doi.org/10.1080/14693062.2014.941317

Akiefnawati, R., Villamor, G. B., Zulfikar, F., Budisetiawan, I., Mulyoutami, E., Ayat, A., \& Noordwijk, M. V. (2010). Stewardship Agreement to Reduce Emissions from Deforestation and Degradation (REDD): Case Study from LubukBeringin’sHutanDesa, Jambi Province, Sumatra, Indonesia. International Forestry Review, 12, 349-360. http://dx.doi.org/10.1505/ifor.12.4.349

Angelsen, A., \& Kaimowitz, D. (1999). Rethinking the Causes of Deforestation: Lessons from Economic Models. The World Bank Research Observer, 14, 73-98. http://www.cifor.org/library/516/rethinking-the-causes-of-deforestation-lessons-from-economic-models/

Angelsen, A., Brown, S., \& Loisel, C. (2009). Reducing Emissions from Deforestation and Forest Degradation (REDD): An Options Assessment Report. http://www.redd-oar.org/links/REDD-OAR_en.pdf 
BPS (2014). Kecamatan Sukadana Dalam Angka 2014 (Sukadana Sub-district in figures 2014). Sukadana: Badan Putsat Statistics Kabupaten Kayong Utara.

Buys, P. (2007). At Loggerheads?: Agricultural Expansion, Poverty Reduction, and Environment in the Tropical Forests. World Bank Publications. http://siteresources.worldbank.org/INTTROPICALFOREST/Resources/2463822-1161184206155/3060670-11616084161 66/PRR-AL_SAOverviewwebnonembargo.pdf

Caplow, S., Jagger, P., Lawlor, K., \& Sills, E. (2011). Evaluating Land Use and Livelihood Impacts of Early Forest Carbon Projects: Lessons for Learning about REDD+. Environmental Science \& Policy, 14, 152-167. http://dx.doi.org/10.1016/j.envsci.2010.10.003

Dixon, R., \& Challies, E. (2015). Making REDD+ Pay: Shifting Rationales and Tactics of Private Finance and the Governance of Avoided Deforestation in Indonesia. Asia Pacific Viewpoint, 56, 6-20. http://dx.doi.org/10.1111/apv.12085

Edwards, D. P., Koh, L. P., \& Laurance, W. F. (2012). Indonesia’s REDD+ Pact: Saving Imperilled Forests or Business as Usual? Biological Conservation, 151, 41-44. http://dx.doi.org/10.1016/j.biocon.2011.10.028

Epule, E. T., Peng, C., Lepage, L., \& Chen, Z. (2014). Policy Options towards Deforestation Reduction in Cameroon: An Analysis Based on a Systematic Approach. Land Use Policy, 36, 405-415.

http://dx.doi.org/10.1016/j.landusepol.2013.09.004

FAO (2015). Global Forest Resources Assessment 2015: How Are the World Forest Changing? Rome: Food and Agriculture Organization of the United Nations.

Geist, H. J., \& Lambin, E. F. (2001). What Drives Tropical Deforestation. LUCC Report Series No. 4, 116. https://www.pik-potsdam.de/members/cramer/teaching/0607/Geist 2001 LUCC Report.pdf

Hiller, M. A., Jarvis, B. C., Lisa, H., Paulson, L. J., Pollard, E. H. B., \& Stanley, S. A. (2004). Recent Trends in Illegal Logging and a Brief Discussion of Their Causes: A Case Study from Gunung Palung National Park, Indonesia. Journal of Sustainable Forestry, 19, 181-212. http://dx.doi.org/10.1300/J091v19n01_09

Jadin, I., Vanacker, V., \& Hoang, H. T. T. (2013). Drivers of Forest Cover Dynamics in Smallholder Farming Systems: The Case of Northwestern Vietnam. Ambio, 42, 344-356. http://dx.doi.org/10.1007/s13280-012-0348-4

Kissinger, G., Herold, M., De Sy, V. (2012). Drivers of Deforestation and Forest Degradation: A Synthesis Report for REDD+ Policymakers. Vancouver: Lexeme Consulting.

Lawrence, D., Peart, D. R., \& Leighton, M. (1998). The Impact of Shifting Cultivation on a Rainforest Landscape in West Kalimantan: Spatial and Temporal Dynamics. Landscape Ecology, 13, 135-148. http://dx.doi.org/10.1023/A:1007985915187

McNeill, D. (2015). Norway and REDD+ in Indonesia: The Art of Not Governing? Forum for Development Studies, 42, 113-132. http://dx.doi.org/10.1080/08039410.2014.997791

Minang, P. A., \& van Noordwijk, M. (2013). Design Challenges for Achieving Reduced Emissions from Deforestation and Forest Degradation through Conservation: Leveraging Multiple Paradigms at the Tropical Forest Margins. Land Use Policy, 31, 61-70. http://dx.doi.org/10.1080/08039410.2014.997791

Minang, P. A., Van Noordwijk, M., Duguma, L. A., Alemagi, D., Do, T. H., Bernard, F., Agung, P., Robiglio, V., Catacutan, D., Suyanto, S., Armas, A., Aguad, C.S., Feudjio, M., Galudra, G., Maryani, R., White, D., Widayati, A., Kahurani, E., Namirembe, S., \& Leimona, B. (2014). REDD+ Readiness Progress across Countries: Time for Reconsideration. Climate Policy, 14, 685-708. http://dx.doi.org/10.1080/14693062.2014.905822

Nagata, J. A. (1974). What Is a Malay? Situational Selection of Ethnic Identity in a Plural Society. American Ethnologist, 1, 331-350. http://dx.doi.org/10.1525/ae.1974.1.2.02a00080

Pasgaard, M. (2013). The Challenge of Assessing Social Dimensions of Avoided Deforestation: Examples from Cambodia. Environmental Impact Assessment Review, 38, 64-72. http://dx.doi.org/10.1016/j.eiar.2012.06.002

Petersen, K., \& Varela, J. B. (2015). INDC Analysis: An Overview of the Forest Sector. Vaud: WWF. http://wwf.panda.org/what_we_do/footprint/forest_climate/forest_climate_publications/?257883/INDC-Analysis-An-Over view-of-the-Forest-Sector

Reid, A. (2001) Understanding Melayu (Malay) as a Source of Diverse Modern Identities. Journal of Southeast Asian Studies, 32, 295-313. http://dx.doi.org/10.1017/S0022463401000157

Salvini, G., Herold, M., De Sy, V., Kissinger, G., Brockhaus, M., \& Skutsch, M. (2014). How Countries Link REDD+ Interventions to Drivers in Their Readiness Plans: Implications for Monitoring Systems. Environmental Research Letters, 9, Article ID: 074004. http://dx.doi.org/10.1088/1748-9326/9/7/074004

Sen, A. (1992). Inequality Reexamined. Oxford: Oxford University Press.

Sen, A. (2001). Development as Freedom. Oxford: Oxford University Press. 
Shoch, D., Eaton, J., \& Settelmyer, S. (2011). Project Developer's Guidebook to VCS REDD Methodologies. Version 1.0. November 2011. Conservation International Carbon Fund.

Soto, S., \& Pintó, J. (2010). Delineation of Natural Landscape Units for Puerto Rico. Applied Geography, 30, 720-730. http://dx.doi.org/10.1016/j.apgeog.2010.01.010

Streck, C., Gomez-Echeverri, L., Gutman, P., Loisel, C., \& Werksman, J. (2009). REDD+ Institutional Options Assessment: Developing an Efficient, Effective, and Equitable Institutional Framework for REDD+ under the UNFCCC. Washington DC: Meridian Institute.

Sunderlin, W. D., Pratama, C. D., Bos, A. B., Avitabile, V., Sills, E. O., de Sassi, C., Joseph, S., Agustavia, M., Pribadi, U. A., \& Anandadas, A. (2014). REDD+ on the Ground: The Need for Scientific Evidence. In E. O. Sills, S. Atmadja, C. de Sassi, A. E. Duchelle, D. Kweka, I. A. P. Resosudarmo, \& W. D. Sunderlin (Eds.), REDD+ on the Ground: A Case Book of Subnational Initiatives across the Globe (pp. 2-21). Bogor: Center for International Forestry Research (CIFOR).

UNFCCC (2010). The Cancun Agreements: Outcome of the Work of the Ad Hoc Working Group on Long-Term Cooperative Action under the Convention. Decision 1/CP16, Cancun. http://unfccc.int/resource/docs/2010/cop16/eng/07a01.pdf

UNFCCC (2013). Nairobi Work Programme on Impacts: Decisions Adopted by the Conference of the Parties. Decision 17/CP19, Warsaw. http://unfccc.int/resource/docs/2013/cop19/eng/10a02r01.pdf

UNFCCC (2015). Adoption of the Paris Agreement: Proposal by the President. Draft Decision -/CP21. http://unfccc.int/resource/docs/2015/cop21/eng/109r01.pdf

Valdivia, C., Barbieri, C., \& Gold, M. A. (2012). Between Forestry and Farming: Policy and Environmental Implications of the Barriers to Agroforestry Adoption. Canadian Journal of Agricultural Economics/Revue Canadienne d'agroeconomie, 60, 155-175. http://dx.doi.org/10.1111/j.1744-7976.2012.01248.x

VCS (2012). Methodology for Avoided Unplanned Deforestation. Approved VCS Methodology VM0015, Version 1.1, Sectoral Scope 14.

Zamzani, F. (2008). Process of Deforestation and Agricultural Expansion in Gunung Palung National Park, West Kalimantan, Indonesia. Master's Thesis, Environmental Sciences, Tsukuba: University of Tsukuba. 